\title{
Applying foliar stoichiometric traits of plants to determine fertilization for a mixed pine-oak stand in the Qinling Mountains, China
}

\author{
Lin Hou Corresp.. ${ }^{1}$ ， Zhenjie Dong ${ }^{1}$ ， Yuanyuan Yang ${ }^{1}$ ， Donghong Zhang ${ }^{1}$ ， Shengli Zhang ${ }^{2}$, Shuoxin Zhang \\ ${ }^{1}$ College of Forestry, Northwest A\&F University, Yangling, Shaanxi, China \\ 2 College of Natural Resources and Environment, Northwest A\&F University, Yangling, Shaanxi, China \\ Corresponding Author: Lin Hou \\ Email address: houlin_1969@nwsuaf.edu.cn
}

Background. The Chinese Natural Forest Protection program has been conducted nationwide and has achieved resounding success. However, timber importation has increased; therefore, producing more domestic timber is critical to meet the demand for raw materials. Fertilization is one of the most effective silviculture practices used to improve tree and stand growth. However, determining the appropriate type and amount of elements is necessary for effective fertilization of big timber in different forest types and environmental conditions. Stoichiometric theory provides the criteria to assess nutrient limitation in plants and offers important insight into fertilizer requirements of forested ecosystems. Methods. Nitrogen (N) and phosphorus (P) concentrations in plants' leaves, mineral soil, and litter were investigated in a mixed pine-oak stand. Results. The big timber rate for Pinus tabuliformis, Pinus armandii and Quercus aliena var. acutesserata is $57.71 \%, 22.79 \%$ and $2.78 \%$ of current existing individuals respectively. Foliar $\mathrm{N}$ and $\mathrm{P}$ concentrations were 9.08 and $0.88 \mathrm{mg} \mathrm{g}^{-1}$, respectively. The $\mathrm{N}$ : $\mathrm{P}$ in the plants was $10.30 . \mathrm{N}$ concentration and $\mathrm{N}$ : $\mathrm{P}$ in mineral soil decreased from $0-30 \mathrm{~cm}$ soil depth. For litter, $\mathrm{N}$ and $\mathrm{P}$ concentrations were 16.89 and $1.51 \mathrm{mg} \mathrm{g}^{-1}$, respectively, and $\mathrm{N}$ : P was 11.51 .

Concentrations of $\mathrm{N}$ and $\mathrm{P}$ in mineral soil and litter did not significantly affect plants'leaf concentrations. Similar result was also obtained between litter and mineral soil concentrations. Nitrogen storage in mineral soil was significantly correlated with foliar N: P in the plants. Discussion. Foliar N:P of dominant tree species and the plants, and foliar N concentration in Pinus tabuliformis and $P$. armandii, and foliar $P$ concentration of $P$. armandii in the mixed pine-oak stand was lower than that in Chinese and other terrestrial plants. Foliar nutrients in the plants were not affected by soil nutrients. According to the criteria of nutrient limitation for plants, growth of dominant tree species was $\mathrm{N}$ limited; therefore, $1.49 \mathrm{t} \mathrm{ha}^{-1}$ pure $\mathrm{N}$ should be added to forest land to as fertilizer. 
1 Applying foliar stoichiometric traits of plants to determine fertilization for a

2 mixed pine-oak stand in the Qinling Mountains, China

3

4

5 Lin Hou ${ }^{1 *}$, Zhenjie Dong ${ }^{1}$, Yuanyuan Yang ${ }^{1}$, Donghong Zhang ${ }^{1}$,Shengli Zhang ${ }^{2}$, Shuoxin

6 Zhang $^{1}$

7

81 College of Forestry, Northwest A\&F University, Yangling, Shaanxi 712100, China

92 College of Natural Resources and Environment, Northwest A\&F University, Yangling,

10 Shaanxi 712100 , China

17 Lin $\mathrm{Hou}$

183 Taicheng Road, Yangling, Shaanxi, 712100, China

19 E-mail: houlin1969@163.com

Tel: +86-29-8708-2124 
21 Abstract

22

23

24

Background. The Chinese Natural Forest Protection program has been conducted nationwide and has achieved resounding success. However, timber importation has increased; therefore, producing more domestic timber is critical to meet the demand for raw materials. Fertilization is one of the most effective silviculture practices used to improve tree and stand growth. However, determining the appropriate type and amount of elements is necessary for effective fertilization of big timber in different forest types and environmental conditions. Stoichiometric theory provides the criteria to assess nutrient limitation in plants and offers important insight into fertilizer requirements of forested ecosystems.

Methods. Nitrogen $(\mathrm{N})$ and phosphorus $(\mathrm{P})$ concentrations in plants' leaves, mineral soil, and litter were investigated in a mixed pine-oak stand.

Results. The big timber rate for Pinus tabuliformis, Pinus armandii and Quercus aliena var. acutesserata is $57.71 \%, 22.79 \%$ and $2.78 \%$ of current existing individuals respectively. Foliar N and $\mathrm{P}$ concentrations were 9.08 and $0.88 \mathrm{mg} \mathrm{g}^{-1}$, respectively. The $\mathrm{N}$ : $\mathrm{P}$ in the plants was 10.30 . $\mathrm{N}$ concentration and N: $\mathrm{P}$ in mineral soil decreased from $0-30 \mathrm{~cm}$ soil depth. For litter, $\mathrm{N}$ and $\mathrm{P}$ concentrations were 16.89 and $1.51 \mathrm{mg} \mathrm{g}^{-1}$, respectively, and N: P was 11.51 . Concentrations of $\mathrm{N}$ and $\mathrm{P}$ in mineral soil and litter did not significantly affect plants'leaf concentrations. Similar result was also obtained between litter and mineral soil concentrations. . Nitrogen storage in mineral soil was significantly correlated with foliar N: P in the plants.

Discussion. Foliar N:P of dominant tree species and the plants, and foliar $\mathrm{N}$ concentration in Pinus tabuliformis and P. armandii, and foliar $\mathrm{P}$ concentration of $P$. armandii in the mixed pine- 
42 oak stand was lower than that in Chinese and other terrestrial plants. Foliar nutrients in the plants

43 were not affected by soil nutrients. According to the criteria of nutrient limitation for plants,

44 growth of dominant tree species was $\mathrm{N}$ limited; therefore, $1.49 \mathrm{t} \mathrm{ha}^{-1}$ pure $\mathrm{N}$ should be added to

45 forest land to as fertilizer.

46

47

48

49

50

51

52

53

54

55

56

57

58

59 


\section{INTRODUCTION}

61 The Natural Forest Protection Program (NFPP) was implemented in China in 1998 and has

62 achieved or surpassed its initial goal by prohibiting commercial logging and partial or full

63 harvesting of timber ( $\mathrm{Xu} 2011$ ). However, the effectiveness of the NFPP has been disputed as it

64 has increased timber imports and caused deterioration in the structures of forest stands (Wang et

65 al. 2013). To redress the insufficient production of domestic timber, the project "Techniques for

66 big timber (diameter at breast height, $\mathrm{DBH}>26 \mathrm{~cm}$ ) cultivation" has been conducted in both

67 northern and southern forests in China. Besides proper forest management (Hou et al. 2017),

68 applying fertilizer is also an efficient way to achieve "big timber". However, determining the

69 appropriate type and amounts of elements is necessary in the cultivation of big timbers in

70 different forest types and environmental conditions.

71 Carbon $(\mathrm{C})$, nitrogen $(\mathrm{N})$, and phosphorus $(\mathrm{P})$ are essential elements for plant growth and

72 metabolic processes (Yang et al. 2015). The relative concentrations of C, N, and P in plants is

73 known as stoichiometry (He et al. 2006), which is a unifying conceptual framework to examine

74 how proportions of elements affect organisms and ecosystems (Danger et al. 2016). The most

75 common limiting elements, $\mathrm{C}, \mathrm{N}$, and $\mathrm{P}$, either individually or in combination, are widespread in

76 terrestrial ecosystems (Venterink et al. 2001; Venterink et al. 2003; Vitousek et al. 2010).

77 Stoichiometric traits, particularly $\mathrm{C}: \mathrm{N}$ and $\mathrm{N}: \mathrm{P}$, are useful indicators of nutrient limitation in

78 both terrestrial ecosystems and ecosystem functioning (Elser et al. 2007; Gundersen et al. 2009). 
79

80

81

82

83

84

85

86

87

88

89

90

91

92

93

94

95

96

97

98

99

In the last two decades, most research in ecological stoichiometry has focused on the causes

and consequences of variation in $\mathrm{C}, \mathrm{N}$, and $\mathrm{P}$ ratios in organisms and their resources; however, there are large disparities in knowledge among taxa, ecosystem types, and specific research topics (Bell et al. 2014; Fanin et al. 2013; Han et al. 2005; He et al. 2006; Knoll et al. 2009; Sardans et al. 2011; Scharler et al. 2015; van Huysen et al. 2016; Venterink and Güsewell 2010; Vrede et al. 2004; Zhan et al. 2017). Leaf stoichiometry of plants, especially $\mathrm{N}$ and $\mathrm{P}$, is very important in analyzing the composition, structure, and function of a community and ecosystem

(Gao et al. 2013; Han et al. 2005; Rong et al. 2015; Venterink and Güsewell 2010). Determining how nutrients limit plant growth and N: P in leaves has become a hot topic (He et al. 2008). Previous studies have documented N: P in plant leaves and biomass to infer or assess the degree of N or P limitation at the community level (Aerts and Chapin 1999; Ellison 2006; Güsewell 2004; Koerselman 1996; Sardans et al. 2012).However, determining the fertilizer of a specific community via ecological stoichiometry theory by assessing $\mathrm{N}$ and $\mathrm{P}$ limitation is still in its infancy (Finn et al. 2016; Hong et al. 2015). We hypothesized that growth of a dominant tree species would not be limited by nutrients when foliar $\mathrm{N}$ : P in the plants meet a threshold (Aerts and Chapin 1999; Güsewell 2004; Koerselman 1996; Sardans et al. 2012). We asked whether the amount of fertilization needed for a concrete forest stand could be determined using current $\mathrm{N}$ and $\mathrm{P}$ storage in mineral soil.

The Qinling Mountains are located in central China and have historically played a vital role in supplying timber for construction. The mixed pine-oak stand is extensive at the mid-altitudinal gradient of the Qinling Mountains (Hou et al. 2017). Maximizing the volume of this forest type 
100 not only increases its carbon sequestration and ecosystem services, but also provides more timber

101 for harvesting. The objectives of this study were to address key knowledge gaps, including: (1)

102 foliar $\mathrm{N}$ and $\mathrm{P}$ stoichiometric traits in the plants in mixed pine-oak stand; (2) the correlation

103 between $\mathrm{N}$ and $\mathrm{P}$ stoichiometry in forest soil and leaves in the plants; (3) nutrient limitation of

104 the plants; and (4) preliminary recommendations for a fertilizer for dominant trees growing

105 normally based on stoichiometric traits.

\section{MATERIALS AND METHODS}

\section{Site description}

108 Experiments were conducted at the Qinling National Forest Ecosystem Research Station

109 (QNFERS), located on the southern slope of the Qinling Mountains, Huoditang, Ningshan

110 County, Shaanxi Province, China $\left(32^{\circ} 18^{\prime} \mathrm{N}, 108^{\circ} 20^{\prime} \mathrm{E}\right)$. The altitude of the study area was from

1111500 to $2500 \mathrm{~m}$. The area has subtropical climate, with annual mean air temperatures around 8-

$11210^{\circ} \mathrm{C}$, annual mean precipitation around $900-1200 \mathrm{~mm}$, and annual mean evaporation around

$113800-950 \mathrm{~mm}$. The main soil type was mountain brown soil, developed from granite material,

114 ranging from $30-50 \mathrm{~cm}$ depth. The total forest area in the station was 2037 hectares. Natural

115 forest occupied 93\% of the total forest area in QNFERS, with various vegetation types

116 distributed along an altitudinal gradient, such as evergreen deciduous mixed forest(mixed pine-

117 oak forest), deciduous broad-leaved forest (oak, red birch), temperate coniferous forest (Chinese

118 red pine, Armand pine), and cold temperate coniferous forest (spruce, fir).The most dominant

119 forest type was mixed pine-oak forest restored after rotation felling between 1950 and 1998 with 120 an average stand age of 42 years and an average height of $9.2 \mathrm{~m}$. Common tree species included

121 Pinus tabuliformis, $P$. armandii, and Quercusaliena var. acuteserrata, associated with

122 Toxicodendron vernicifluum, Carpinus turczaninowii, Swida macrophylla, Acer mono, Tilia 
123

124

125

126

127

128

129

130

131

132

133

134

135

136

137

138

139

140

141

142

143

144

145

paucicostata, Carpinus cordata, Juglans cathayensis, Bothrocaryum controversum, Rhus

potaninii, Dendrobenthamia japonica var. Chinensis, Pterocarya stenoptera, Acer davidii,

Betula albo-sinensis, Betula albo-sinensis var. septentrionalis, Juglans mandshurica, Rhus

punjabensis Stewart var. sinica, Prunus padus, and Sorbus folgneri, and understory species were abundant (Hou et al. 2017).

Field investigations and sampling were conducted from 10 to 15 September, 2014. Samples

of trees litter and soils were collected from 13 long-term fixed plots in the mixed pine-oak stand.

Each plot was $20 \times 20 \mathrm{~m}$. Tree species, number, Height $(\mathrm{H})$, and diameter at breast height $(\mathrm{DBH})$

were recorded and used to determine the dominant tree species and DBH classes. Each increase

in $\mathrm{DBH}$ by 4 cmis a DBH class and mid-diameter is used to stand for it (DBH ranging from 6.1

to $10 \mathrm{~cm}$, the corresponding mid-diameter is $8 \mathrm{~cm}$ ). One hundred and fifty-six of the average

standard trees (AST) in all DBH classes were determined in each of the 13 plots

(Supplementary). Mature, sunlit leaves without disease or insect pests were sampled. Four

leaves/needles from each AST were collected in each of the four directions (north, east, south

and west) and at different stem heights (crown, intermediate section, and underpart), and mixed

into one sample for each AST. Five subplots $(1 \times 1 \mathrm{~m})$ within each plot were randomly

established to collect litter and mineral soil (depth 0-30 cm, $10 \mathrm{~cm}$ each layer). Samples of litter

were collected manually and soil samples were collected by an auger (internal diameter $38 \mathrm{~mm}$ ).

Soil volumetric rings $\left(100 \mathrm{~cm}^{3}\right)$ were also used to collect soil samples to measure soil bulk

density using the cutting ring method. Five samples of litter and mineral soil from the same

depth within each subplot were mixed into one sample. All samples (litter and mineral soil) were

weighed in the field before being transported to the laboratory. 
147 ground using a plant sample mill and sieved through a 1-mm mesh screen. Nitrogen

148 concentrations in leaves/needles and litter were measured using a flow injection analyzer

149 (FIA5000, FOSS, Sweden), while P concentrations were measured using the molybdenum blue 150 colorimetric method after digestion in a $\mathrm{H}_{2} \mathrm{SO}_{4}+\mathrm{H}_{2} \mathrm{O}_{2}$ solution (Bao 2000). Auger soil samples

151 were air-dried under shade, then ground and sieved though a 0.149-mm mesh. Total soil N (TN)

152 was measured using the Kjeldahl method (Kjeltec TM 8400, FOSS, Sweden), and total soil P

153 (TP) was determined using acid digestion in $\mathrm{H}_{2} \mathrm{SO}_{4}+\mathrm{HClO}_{4}$ solution(Bao 2000).

154 Data processing

Importance values (IV) of tree species were calculated following Busby et al. (2010):

$$
\mathrm{RH}=\frac{\sum \mathrm{H}_{\mathrm{i}}}{\mathrm{H}} \times 100 \%
$$

where, $\mathrm{RH}$ is the relative height, $\mathrm{H}_{\mathrm{i}}$, is the height of tree species $i$, and $\mathrm{H}$ is the height of all

158

159

160

161

162

163

164

165

166

167

$$
\mathrm{RF}=\frac{\Sigma \mathrm{F}_{\mathrm{i}}}{\mathrm{F}} \times 100 \%
$$

where, RF is the relative frequency, $\mathrm{F}_{i}$ is the frequency of tree species $i$, and $\mathrm{F}$ is the frequency of all tree species in all plots.

$$
\mathrm{RD}=\frac{\frac{1}{4} \pi \mathrm{f} \sum \mathrm{D}_{\mathrm{i}}^{2}}{\mathrm{D}^{2}}
$$

where, $\mathrm{RD}$ is the relative basal area, $\mathrm{D}_{\mathrm{i}}$ is the $\mathrm{DBH}$ of tree species $i$, $\mathrm{D}$ is the basal area of all tree species in all plots, and $\mathrm{f}$ is the form factor of tree species $\left(\mathrm{f}_{\text {conifer }}=0.40, \mathrm{f}_{\text {broadleaf }}=0.42\right)$.

$$
\mathrm{IV}=\frac{\mathrm{RH}+\mathrm{RF}+\mathrm{RD}}{3} \times 100 \%
$$

Tree species with IV $>10 \%$ were determined as dominant.

The big timber rate of dominant tree species was calculated as following. 


$$
\mathrm{R}_{\mathrm{bi}}=\frac{\mathrm{N}_{\mathrm{bi}}}{\mathrm{N}_{\mathrm{i}}} \times 100 \%
$$

where $\mathrm{R}_{\mathrm{bi}}$ is big timber rate (\%) of tree species $\mathrm{i}, \mathrm{N}_{\mathrm{bi}}$ is stems of big timber of tree species $\mathrm{i}$ and $\mathrm{N}_{\mathrm{i}}$ is total stems of tree species $\mathrm{i}$ in the plots.

Nitrogen and P stoichiometry ( $\mathrm{N}$ and $\mathrm{P}$ concentration and $\mathrm{N}$ : P) of plants' leaves was calculated following Du et al. (2011):

$$
\mathrm{S}_{\mathrm{t}}=\sum_{\mathrm{i}=1}^{\mathrm{n}} \mathrm{C}_{\mathrm{ni}} \times \mathrm{IV}_{\mathrm{i}}
$$

where, $\mathrm{S}_{\mathrm{t}}$ is $\mathrm{N}$ and $\mathrm{P}$ stoichiometry of all tree species, $\mathrm{C}_{\mathrm{ni}}$ is the concentration of $\mathrm{N}$ or $\mathrm{P}(\mathrm{mg}$ $\left.\mathrm{g}^{-1}\right)$ or $\mathrm{N}$ : $\mathrm{P}$ in leaves of tree $i, \mathrm{IV}_{\mathrm{i}}$ is the importance value of tree $i$, and $\mathrm{n}$ is the number of dominant tree species.

Nutrient storage $\left(\mathrm{t} \mathrm{ha}^{-1}\right)$ in litter was calculated as follows:

$$
\mathrm{S}_{\mathrm{l}}=\mathrm{C}_{\mathrm{l}} \mathrm{B}_{\mathrm{l}}
$$

where, $\mathrm{S}_{1}$ is the litter nutrient storage $\left(\mathrm{t} \mathrm{ha}^{-1}\right), \mathrm{C}_{1}$ is element $(\mathrm{N}$ or $\mathrm{P})$ concentration $\left(\mathrm{mg} \mathrm{g}^{-1}\right)$, and $\mathrm{B}_{1}$ is the biomass $\left(\mathrm{t} \mathrm{ha}^{-1}\right)$.

Storage of nutrients $(\mathrm{N}$ and $\mathrm{P})$ in soil was calculated as follows:

$$
\mathrm{S}_{\mathrm{T}}=\sum_{\mathrm{i}=1}^{\mathrm{n}} \mathrm{E}_{\mathrm{i}} \mathrm{B}_{\mathrm{i}} \mathrm{D}_{\mathrm{i}}
$$

where, $\mathrm{S}_{\mathrm{T}}$ is the soil nutrient storage $\left(\mathrm{tha}^{-1}\right), \mathrm{E}_{\mathrm{i}}$ is the concentration of element $i\left(\mathrm{mg} \mathrm{g}^{-1}\right), \mathrm{B}_{\mathrm{i}}$ is the bulk density $\left(\mathrm{g} \mathrm{cm}^{-3}\right)$ in layer $i$, and $\mathrm{D}_{\mathrm{i}}$ is depth $i(\mathrm{~cm})$.

Differences of N, P concentrations and N: P between dominant tree species were analyzed using Statistical Analysis of the T-Test. The extremely significant difference $(p<0.01)$, significant difference $(0.01<p<0.05)$ and not significant difference $(p>0.05)$ between paired variables were demonstrated as different capital letters, different lowercase letters and the same lowercase letter respectively. The correlations between foliar $\mathrm{N}$ and $\mathrm{P}$ and $\mathrm{N}$ : $\mathrm{P}$ in the plants, 
190 foliar N and P, N: P in the plants and mineral soil, and litter were assessed using Spearman's

191 rank correlation. Significance levels were set at $p=0.05$. All statistical analyses were performed

192 using SPSS software (version 19.0 for Windows; SPSS Inc., Chicago, IL, USA). Figures were

193 plotted using Origin 8.0 (OriginLab Corporation, Northampton, Massachusetts, USA).

\section{RESULTS}

195

196

197

198

199

200

201

202

\section{Dominant tree species}

There were 21 tree species in the mixed pine-oak stand. Aside from the photophilous species (P. tabuliformis, $P$. armandii, and $Q$. aliena var.acuteserrata), most of the species were shade-tolerant (Toxicodendron vernicifluum, Carpinus turczaninowii) or neutral with respective to light (Acer mono, Sorbus folgneri) (Table 1). The dominant tree species with importance values $>10 \%$ were $P$. tabuliformis, $P$. armandii, and $Q$. aliena var.acuteserrata (Table 1$)$.

The big timber rate for $P$. tabuliformis, $P$. armandii, and $Q$. aliena var. acuteserrata was $57.71 \%, 22.79 \%$ and $2.78 \%$ of current existing individuals respectively (Table 2 ).

\section{Patterns of foliar $N$ and $P$ and $N: P$ in the plants}

Foliar N $\left(11.84 \pm 2.36 \mathrm{mg} \mathrm{g}^{-1}\right.$ to $\left.21.72 \pm 3.19 \mathrm{mg} \mathrm{g}^{-1}\right)$ and $\mathrm{P}\left(1.20 \pm 0.14 \mathrm{mgg}^{-1}\right.$ to $2.00 \pm 0.31$ $\mathrm{mg} \mathrm{g}^{-1}$ ) and $\mathrm{N}: \mathrm{P}(9.62$ to 10.87$)$ exhibited large variation among tree species (Table 3$)$. The general trend demonstrated that foliar nutrients and $\mathrm{N}$ : $\mathrm{P}$ of $P$. tabuliformis and $P$. armandii were less than that in Q. aliena var. acuteserrata (Table 3). Moreover, foliar stoichiometric variables of the plants were also less than those in individual tree species in the mixed pine-oak stand (Table 3). 
210 In the plants, concentrations of foliar $\mathrm{N}$ and $\mathrm{P}$ were significantly, positively correlated

$211(p=0.000)$ with each other (Figure 1(a)). The mathematical Log foliar $\mathrm{N}$ concentration was

212 significantly ( $p=0.02$ ), positively correlated with the $\log \mathrm{N}$ : P (Figure1 (b)). Foliar P

213 concentration and $\mathrm{N}$ : $\mathrm{P}$ were significantly, negatively correlated $(p=0.000)$ with each other

214 (Figure1 (c)).

215 Patterns of $\mathbf{N}$ and $\mathbf{P}$ and $\mathbf{N}$ : $\mathbf{P}$ in mineral soil and litter

216 Nitrogen concentrations and N: P varied markedly across mineral soil at 0-30 $\mathrm{cm}$ depth,

217 ranging from $0.60 \pm 0.05 \mathrm{mg} \mathrm{g}^{-1}$ to $2.40 \pm 0.10 \mathrm{mg} \mathrm{g}^{-1}$ and $2.60 \pm 0.41$ to $6.81 \pm 0.51$, respectively

218 (Table 4). However, $\mathrm{P}$ in mineral soil at 0-30 $\mathrm{cm}$ depth was significantly different, ranging from

219

220

221

222

223

224

225

226

227

228

229

$0.23 \pm 0.03 \mathrm{mg} \mathrm{g}^{-1}$ to $0.36 \pm 0.03 \mathrm{mg} \mathrm{g}^{-1}$ (Table 4). Bulk density of mineral soil increased with soil depth (Table 4). The indices, mean N: P and concentrations of $\mathrm{N}$ and $\mathrm{P}$ in litter were 2.49, 12.06 and 5.21 times of which in mineral soil respectively (Table 4).

Correlations between $\mathrm{N}$ and $\mathrm{P}$ concentrations in litter and mineral soil were complex and none was significant (Figure 2(a) and (b)). At 0-10 cm depth, mineral soil $\mathrm{N}$ concentration increased with litter $\mathrm{N}$ concentration when litter $\mathrm{N}$ concentration was $<17.9 \mathrm{mg} \mathrm{g}^{-1}$, and vice versa (Figure 2(a)). Soil P concentration increased with litter P concentration (Figure 2(b)). At 11-20 cm depth, mineral soil $\mathrm{N}$ concentration decreased with litter $\mathrm{N}$ concentration when litter $\mathrm{N}$ concentration was $<19.0 \mathrm{mg} \mathrm{g}^{-1}$, and vice versa (Figure 2 (a)). Soil P concentration showed an exponential correlation with litter P concentration (Figure 2(b)). At 21-30 cm depth, mineral soil $\mathrm{N}$ concentration increased with litter $\mathrm{N}$ concentration when litter $\mathrm{N}$ concentration was $<17.9 \mathrm{mg}$ 
$230 \mathrm{~g}^{-1}$, and vice versa (Figure 2(a)). Phosphorus concentration of mineral soil increased linearly with

231 litter P concentration (Figure 2(b)).

232 Correlation between foliar $\mathbf{N}$ and $\mathbf{P}$ concentration in the plants and mineral soil

233 Foliar $\mathrm{N}$ concentration in the plants increased with $\mathrm{N}$ concentration of mineral soil at 0 -

$23410 \mathrm{~cm}$ depth (Figure 3(a)). In contrast, foliar P concentration in the plants showed a significant,

235 cubic correlation with P concentration of mineral soil $(p=0.048)$ (Figure 3(b)). Although foliar $\mathrm{N}$

236 and $\mathrm{P}$ concentrations in the plants were not significantly $(p=0.09)$ correlated with mineral soil at

$237 \quad 11-20 \mathrm{~cm}$ depth, foliar $\mathrm{N}$ concentration in the plants increased with $\mathrm{N}$ concentration of mineral

238 soil (Figure 3(a) and (b)). There was no correlation between foliar $\mathrm{N}$ concentration in the plants

239 and $\mathrm{N}$ concentration of mineral soil at 21-30 cm depth (Figure 3(a)). Foliar P concentration in

240 the plants increased with P concentration of mineral soil at 21-30 cm depth (Figure 3(b)).

241 DISCUSSION

242 Foliar $\mathbf{N}$ and $\mathbf{P}$ stoichiometric traits in the plants in mixed pine-oak stand

243 The positive correlation between foliar $\mathrm{N}$ and $\mathrm{P}$ concentrations $(p=0.000$, Figure1 (a)) in the

244 plants is consistent with stoichiometric stability criteria of a fixed ratio of nutrient absorption in

245 the plant (Koerselman 1996). Previously, mean foliar N and P and N: P were reported as 18.6,

$2461.21 \mathrm{mg} \mathrm{g}^{-1}$, and 14.4, respectively for 753 species of terrestrial plants across China (Han et al.

247 2005) and 18.3, $1.42 \mathrm{mg} \mathrm{g}^{-1}$, and 11.8 , respectively for 1251 world terrestrial plants (Reich and

248 Oleksyn 2004). This study indicated that foliar N: P of dominant tree species (P. tabuliformis, $P$.

249 armandii, and Quercusaliena var. acuteserrata.) and in the plants (10.30:1) were lower than both

250 Chinese and global terrestrial plants. Similarly, foliar N concentration of P. tabuliformis 
$251 \quad\left(11.84 \pm 1.40 \mathrm{mg} \mathrm{g}^{-1}\right)$ and $P$. armandii $\left(12.98 \pm 1.43 \mathrm{mg} \mathrm{g}^{-1}\right)$, and foliar P concentration of $P$.

252 armandii $\left(1.20 \pm 0.14 \mathrm{mg} \mathrm{g}^{-1}\right)$ were also lower. The overall element composition of plants in an 253 ecosystem is determined by the mix of species and by the physiological status of the dominant

254 plants (Güsewell 2004).Therefore, potential explanations for the observed patterns are that foliar

255 element concentrations and ratios were strongly determined by genetic and physiological

256 controls, and that these crucial factors prevented plants from responding to the natural

257 availability of nutrients (Castle and Neff 2009). Furthermore, the nutrient status of terrestrial

258 plants has a strong local and regional signal due to acquiring nutrients via weathering and

259 microbial decomposition in situ (Chadwick et al. 1999). In the study area, low air temperature

$260\left(<10^{\circ} \mathrm{C}\right)$ (Hou et al. 2017) may have hindered rock weathering and microbial activity. However,

261 the concentration of foliar $\mathrm{N}\left(21.72 \pm 3.19 \mathrm{mg} \mathrm{g}^{-1}\right)$ and $\mathrm{P}\left(2.00 \pm 0.31 \mathrm{mg} \mathrm{g}^{-1}\right)$ in $Q$. aliena var.

262 acuteserrata was higher than that reported for Chinese and global mean levels. Foliar P

263 concentration of $P$. tabuliformis $\left(1.23 \pm 0.22 \mathrm{mg} \mathrm{g}^{-1}\right)$ was higher than the Chinese mean, but

264 lower than the global mean. The growing period (from mid-May to late-September) in the study

265 area was relatively short for plots on high elevation (more than $1600 \mathrm{~m}$ ) (Hou et al. 2017). The

266 leaf life span of $P$. tabuliformis and $P$. armandii in the study area is 3 years. In the contrary, the

267 leaf life span of Q. aliena var. acuteserrata is only 5 months. Therefore, shorter leaf life span

268 and growing season may have caused higher N and P concentrations (Castle and Neff 2009; He

269 et al. 2006).

270 Response of foliar nutrients in the plants to soil nutrients 
The $\mathrm{N}$ and $\mathrm{P}$ concentrations in mineral soil were generally low and the similar result was

272 also found by $\mathrm{Wu}(2015)$. The $\mathrm{N}$ concentration in the top layer of mineral soil $(0-10 \mathrm{~cm})$ was

273 above the standard of first class soil $\left(>2.0 \mathrm{~g} \mathrm{~kg}^{-1}\right)$ (National Soil Survey Office of China 1998);

274 however, at 11-20 cm depth it only met the standard of third class soil (1-1.5 $\left.\mathrm{g} \mathrm{kg}^{-1}\right)$, and at 21-

$27530 \mathrm{~cm}$ it met the standard of fifth class soil $\left(0.5-0.75 \mathrm{~g} \mathrm{~kg}^{-1}\right)$ (National Soil Survey Office of

276 China 1998). The level of soil P concentration at $0-30 \mathrm{~cm}$ only reached the standard of third

277 class soil (0.2-0.4 $\left.\mathrm{g} \mathrm{kg}^{-1}\right)$ (National Soil Survey Office of China 1998). Litter decomposition and

278 rock weathering are the main nutrient sources for mineral soil in natural forests. Plant element

279 concentrations are largely determined by supplies of elements in soil and the chemical and

280 physical characteristics of soil environments (Castle and Neff 2009). However, our findings

281 demonstrated that elements in litter did not significantly affect mineral soil. We found most of

282 the correlations between foliar $\mathrm{N}$ and $\mathrm{P}$ concentrations in the plants and mineral soil at various

283 depths were not significant, and soil nutrients did not explain more than $14 \%$ of foliar nutrients

284 in the plants. Therefore, these results were not able to provide a better understanding and

285 interpretation of the effects of litter and soil nutrients on mineral soil and foliar nutrients in the

286 plants. Possible explanations for the observed patterns include high non-soluble chemical

287 compounds in litter and low temperature (Hou et al. 2017), which slowed down litter

288 decomposition. Furthermore, soil available $\mathrm{N}$ and $\mathrm{P}$ absorbed by plants have strong mobility and

289 are easily leached (Thompson et al. 2010). The thickness of mineral soil (at 30-50 cm depth),

290 pore ratio from 32.0 to $62.28 \%$, high precipitation $(800-1200 \mathrm{~mm}$ ), and low temperature (Hou et

291 al. 2010, 2017) in the study area may have accelerated leaching of $\mathrm{N}$ and $\mathrm{P}$ in decomposed litter

292 and mineral soil, leaving less $\mathrm{N}$ and $\mathrm{P}$ to be assimilated into leaves of the plants. In addition, 
293 forest harvesting in 1950-1998 was also key cause to decrease $\mathrm{N}$ and P concentrations in mineral 294 soil.

\section{Nutrient limitation of plants}

296 It has been suggested that biomass N: P may be a better indicator of $\mathrm{N}$ or P deficiency than 297 nutrient concentrations (Güsewell et al. 2003). Previous studies have reported that plant growth 298 is limited by concurrent $\mathrm{N}$ concentration $<20 \mathrm{mg} \mathrm{g}^{-1}$ and $\mathrm{N}$ : $\mathrm{P}<14$; while $\mathrm{P}$ limits plant growth at 299 concentrations of $<1 \mathrm{mg} \mathrm{g}^{-1}$ and $\mathrm{N}$ : $\mathrm{P}>16$. Therefore, co-limitation of $\mathrm{N}$ and $\mathrm{P}$ will occur when the concentrations and ratio of $\mathrm{N}$ and $\mathrm{P}$ meet these conditions (Aerts and Chapin 1999; Koerselman 1996). The foliar N: P (10.3) and N concentration $\left(9.08 \mathrm{mg} \mathrm{g}^{-1}\right)$ of the plants in the mixed pineoak (Table 3) stand showed $\mathrm{N}$ limitation according to above mentioned criteria (Aerts and

303

304

306

307 308

309

310

311

312 313 314

Chapin 1999; Koerselman 1996).

The correlations between soil nutrient storage and foliar N: P of the plants indicated that foliar N: P of the plants was correlated with soil N storage (Figure 4(a)). One possible reason may be that the growth of the plants was limited by $\mathrm{N}$, and foliar $\mathrm{N}$ : P of the plants responses to soil $\mathrm{N}$ were more sensitive. However, $\mathrm{N}$ storage in mineral soil only explained $40 \% \quad$ (Figure 4(a)) of the variation in foliar $\mathrm{N}$ : P of the plants, and foliar $\mathrm{N}$ : P of the plants was not significantly correlated with soil P storage (Figure 4(b)). This may have been a result of low P concentration in mineral soil, which also affected foliar N: P of the plants.

Our results showed that the total standing crop of elements in litter was estimated as $0.31 \pm 0.07 \mathrm{t} \mathrm{ha}^{-1}$ for $\mathrm{N}$, and $0.02 \pm 0.01 \mathrm{tha}^{-1}$ for $\mathrm{P}$; and $4.58 \pm 0.15 \mathrm{tha}^{-1}$ for $\mathrm{N}$ and $0.95 \pm 0.09 \mathrm{t} \mathrm{ha}^{-1}$ for $\mathrm{P}$ in mineral soil at $0-30 \mathrm{~cm}$ depth (Table 4). This suggested that trees might assimilate $\mathrm{N}$ and P entirely from that stored in mineral soil and litter. According to the criteria (Aerts and Chapin 
315 1999; Koerselman 1996), $1.49 \mathrm{t} \mathrm{ha}^{-1}$ pure $\mathrm{N}$ should be used to fertilize forest land to relieve $\mathrm{N}$

316 limitation on tree growth.

317 Limitations of the analysis

318 We analyzed stoichiometric traits of leaves in the plants, mineral soil, and litter to explore

319 the effects of $\mathrm{N}$ and $\mathrm{P}$ concentrations and $\mathrm{N}$ : $\mathrm{P}$ of litter and mineral soil on leaves in the plants.

320 We also investigated the correlations between foliar $\mathrm{N}$ : P in the plants and $\mathrm{N}$ and $\mathrm{P}$ storage in

321 mineral soil. The factors included in this study only explained $40 \%$ of the variation, which

322 prevented us from fully understanding and interpreting total variation. Furthermore, besides

323 criteria we used in the study, a more conservative estimate of $\mathrm{N}$ : $\mathrm{P}$ threshold is $<10$ for $\mathrm{N}$

324 limitation and $>20$ for P limitation (Güsewell 2004; Sardans et al. 2012). Since there are multiple

325 criteria for assessing nutrient limitation (Aerts and Chapin 1999; Güsewell 2004; Koerselman

326 1996; Sardans et al. 2012), we lack sufficient evidence to support an accurate estimation of

327 fertilizer application rate. Finally, nutrient use efficiency and its influence on tree growth was not

328 included in the estimation of pure $\mathrm{N}$ application rate, as it would have underestimated N. To

329 verify these preliminary results, more study is required to detect the effects of fertilizer on

330 stoichiometric traits of trees and mineral soil, and $\mathrm{N}$ and $\mathrm{P}$ interactions.

\section{CONCLUSIONS}

Our results indicated that $\mathrm{N}$ and $\mathrm{P}$ concentrations were low in leaves in the plants and mineral soil, but high in litter. Concentrations of $\mathrm{N}$ and $\mathrm{P}$ in mineral soil were insufficient to explain the variation in foliar $\mathrm{N}$ : $\mathrm{P}$ in the plants. However, $\mathrm{N}$ storage in mineral soil at $0-30 \mathrm{~cm}$ depth was correlated with foliar N: P. The growth of the plants was limited by N; therefore, the stoichiometric approach we used in the present study reveals that approximately $1.49 \mathrm{tha}^{-1}$ of $\mathrm{N}$

337 should be added if we want to achieve big timber cultivation. However, these rates should be 
338 further confirmed by a field fertilization experiments. We further recommend that appropriate

339 fertilization rates should be included in the process of big timber cultivation. This result offers

340 important insights into fertilizing forest land.

\section{ACKNOWLEDGEMENTS}

342 We thank staff at Huoditang Forest Farm, Northwest A\&F University for their assistance

343 with sampling.

344 Data Availability

345 The following information was supplied regarding data availability:

346 The raw data has been supplied as Supplementary File. 
347

348

349

350

351

352

353

354

355

356

357

358

359

360

361

362

363

364

365

366

367

368

369

370

371

372

373

\section{REFERENCES}

Aerts R, and Chapin FSI. 1999. The mineral nutrition of wild plants revisited: a re-evaluation of processes and patterns. Advances in Ecological Research 30:1-67.

Bao SD. 2000. Soil and Agricultural Chemistry Analysis. Beijing: China Agriculture Press.

Bell C, Carrillo Y, Boot CM, Rocca JD, Pendall E, and Wallenstein MD. 2014.

Rhizosphere stoichiometry: are $\mathrm{C}: \mathrm{N}: \mathrm{P}$ ratios of plants, soils, and enzymes conserved at the plant species-level? New Phytologist 201:505-517.

Busby PE, Vitousek P, and Dirzo R. 2010. Prevalence of tree regeneration by sprouting and seeding along a rainfall gradient in Hawai'i. Biotropica 42:80-86.

Castle SC, and Neff JC. 2009. Plant response to nutrient availability across variable bedrock geologies. Ecosystems 12:101-113.

Chadwick OA, Derry LA, Vitousek PM, Huebert BJ, and Hedin LO. 1999. Changing sources of nutrients during four million years of ecosystem development. Nature 397:491-497.

Danger M, Gessner MO, and Bärlocher F. 2016. Ecological stoichiometry of aquatic fungi: curruent knowledge and perspectives. Fungal Ecology 19:100-111.

Du Y, Pan G, Li L, Hu Z, and Wang X. 2011. Leaf N/P ratio and nutrient reuse between dominant species and stands: predicting phosphorus deficiencies in Karst ecosystems, southwestern China. Environmental Earth Sciences 64:299-309.

Ellison AM. 2006. Nutrient limitation and stoichiometry of carnivorous plants. Plant Biology 8:740-747.

Elser JJ, Bracken MES, Cleland EE, Gruner DS, Harpole WS, Hillebrand H, Ngai JT, Seabloom EW, Shurin JB, and Smith JE. 2007. Global analysis of nitrogen and phosphorus limitation of primary producers in freshwater, marine and terrestrial ecosystems. Ecology Letters 10:1135-1142.

Fanin N, Fromin N, Buatois B, and Hättenschwiler S. 2013. An experimental test of the hypothesis of non-homeostatic consumer stoichiometry in a plant litter-microbe system. 
Ecology Letters 16:764-772.

Finn D, Page K, Catton K, Kienzle M, Robertson F, Armstrong R, and Dalal R. 2016. Ecological stoichiometry controls the transformation and retention of plant-derived organic matter to humus in response to nitrogen fertilisation. Soil Biology and Biochemistry 99:117-127.

Güsewell S. 2004. N : P ratios in terrestrial plants: variation and functional significance. New Phytologist 164:243-266.

Güsewell S, Koerselman W, and Verhoeven JTA. 2003. Biomass N: P ratios as indicators of nutrient limitation for plant populations in wetlands. Ecological Applications 13:372-384.

Gao Y, Yu G, and He N. 2013. Equilibration of the terrestrial water, nitrogen, and carbon cycles: advocating a health threshold for carbon storage. Ecological Engineering 57:366-374.

Gundersen P, Sevel L, Christiansen JR, Vesterdal L, Hansen K, and Bastrup-Birk A. 2009. Do indicators of nitrogen retention and leaching differ between coniferous and broadleaved forests in Denmark? Forest Ecology and Management 258:1137-1146.

Han W, Fang J, Guo D, and Zhang Y. 2005. Leaf nitrogen and phosphorus stoichiometry across 753 terrestrial plant species in China. New Phytologist 168:377-385.

He JS, Fang J, Wang Z, Guo D, Flynn DFB, and Geng Z. 2006. Stoichiometry and large-scale patterns of leaf carbon and nitrogen in the grassland biomes of China. Oecologia 149:115-122.

He JS, Wang L, Dan FBF, Wang X, Ma W, and Fang J. 2008. Leaf Nitrogen:Phosphorus stoichiometry across Chinese grassland biomes. Oecologia 155:301-310.

Hong J, Wang X, and Wu J. 2015. Effects of soil fertility on the N:P stoichiometry of herbaceous plants on a nutrient-limited alpine steppe on the northern Tibetan Plateau. Plant and Soil 391:179-194.

Hou L, Lei R, Zhang S, and Liu J. 2010. Temporal and spatial variations of soil respiration in Pinus tabulaeformis forest at Huoditang forest zone in the Qinling Mountains,China. 
401

402

403

404

405

406

407

408

409

410

411

412

413

414

415

416

417

418

419

420

421

422

423

424

425

426

427

Acata Ecologica Sinica 30:5225-5236.

Hou L, Sun S, Liang L, Liang G, and Jiang L. 2017. Effects of selective thinning and residue removal on ground layer structure and diversity in a mixed pine-oak stand of the Qinling Mountains, China. Australian Journal of Botany 65:485-496.

Knoll LB, McIntyre PB, Vanni MJ, and Flecker AS. 2009. Feedbacks of consumer nutrient recycling on producer biomass and stoichiometry: separating direct and indirect effects. Oikos 118:1732-1742.

Koerselman W. 1996. The vegetation N:P ratio: a new tool to detect the nature of nutrient limitation. Journal of Applied Ecology 33:1441-1450.

National Soil Survey Office of China. 1998. Soils of China. Beijing, China: Chinese Agriculture Press.

Reich PB, and Oleksyn J. 2004. Global patterns of plant leaf $N$ and $P$ in relation to temperature and latitude. Proceedings of the National Academy of Sciences of the United States of America 101:11001-11006.

Rong Q, Liu J, Cai Y, Lu Z, Zhao Z, Yue W, and Xia J. 2015. Leaf carbon, nitrogen and phosphorus stoichiometry of Tamarix chinensis Lour. in the Laizhou Bay coastal wetland, China. Ecological Engineering 76:57-65.

Sardans J, Rivas-Ubach A, and Peñuelas J. 2011. Factors affecting nutrient concentration and stoichiometry of forest trees in Catalonia (NE Spain). Forest Ecology and anagement 262:2024-2034.

Sardans J, Rivasubach A, and Peñuelas J. 2012. The elemental stoichiometry of aquatic and terrestrial ecosystems and its relationships with organismic lifestyle and ecosystem structure and function: a review and perspectives. Biogeochemistry 111:1-39.

\section{Scharler UM, Ulanowicz RE, Fogel ML, Wooller MJ, Jacobson-Meyers ME, Lovelock} CE, Feller IC, Frischer M, Lee R, McKee K, Romero I C, Schmit J P, Shearer C. 2015.

Variable nutrient stoichiometry (carbon:nitrogen:phosphorus) across trophic levels 
determines community and ecosystem properties in an oligotrophic mangrove system. Oecologia 179:863-876.

430

431

432

433

434

435

436

437

438

439

440

441

442

443

444

445

446

447

448

449

450

451

452

453

454

Thompson K, Parkinson JA, Band SR, and Spencer RE. 2010. A comparative study of leaf nutrient concentrations in a regional herbaceous flora. New Phytologist 136:679-689.

van Huysen TL, Perakis SS, and Harmon ME. 2016. Decomposition drives convergence of forest litter nutrient stoichiometry following phosphorus addition. Plant and Soil 406:1-14.

Venterink HO, and Güsewell S. 2010. Competitive interactions between two meadow grasses under nitrogen and phosphorus limitation. Functional Ecology 24:877-886.

Venterink HO, Vliet REVD, and Wassen MJ. 2001. Nutrient limitation along a productivity gradient in wet meadows. Plant and Soil 234:171-179.

Venterink HO, Wassen MJ, Verkroost AWM, and Ruiter PCD. 2003. Species richness-productivity patterns differ between N-, P-, and K-limited wetlands. Ecology 84:2191-2199.

Vitousek PM, Porder S, Houlton BZ, and Chadwick OA. 2010. Terrestrial phosphorus limitation: mechanisms, implications, and nitrogen-phosphorus interactions. Ecological Applications A Publication of the Ecological Society of America 20:5.

Vrede T, Dobberfuhl DR, Kooijman SALM, and Elser JJ. 2004. Fundamental connections among organism $\mathrm{C}: \mathrm{N}: \mathrm{P}$ stoichiometry, macromolecular composition, and growth. Ecology 85:1217-1229.

Wang W, Pechacek P, Zhang M, Xiao N, Zhu J, and Li J. 2013. Effectiveness of nature reserve system for conserving tropical forests: a statistical evaluation of Hainan Island, China. Plos One 8:e57561.

Wu H. 2015. The relationship between terrain factors and spatial variability of soil nutrients for pine-oak mixed forest in Qinling Mountains. Journal of Natural Resources 30: 858869.

Xu J. 2011. China's new forests aren't as green as they seem. Nature 477:371-371. 
455 Yang X, Huang Z, Zhang K, and Cornelissen JHC. 2015. C:N:P stoichiometry of Artemisia 456 species and close relatives across northern China: unravelling effects of climate, soil and taxonomy. Journal of Ecology 103:1020-1031.

459

Zhan S, Wang Y, Zhu Z, Li W, and Bai Y. 2017. Nitrogen enrichment alters plant N: P stoichiometry and intensifies phosphorus limitation in a steppe ecosystem. Environmental and Experimental Botany 134:21-32. 


\section{Table $\mathbf{1}$ (on next page)}

Importance value of tree species

$\mathrm{RH}, \mathrm{RD}, \mathrm{RF}$ and IV in the table represent relative frequency, relative basal area and important value of tree species respectively. 
Table1 Importance value of tree species

\begin{tabular}{ccccc}
\hline Species & RH (\%) & RD (\%) & RF (\%) & IV (\%) \\
\hline Pinus tabuliformis & 30.9 & 65.2 & 9.4 & 35.2 \\
Pinus armandi & 24.1 & 27.5 & 8.7 & 20.1 \\
Quercus aliena var. acuteserrata & 16.3 & 5.1 & 10.2 & 10.6 \\
Toxicodendron vernicifluum & 7.0 & 1.3 & 8.7 & 5.6 \\
Carpinus turczaninowii & 2.2 & 0.1 & 8.7 & 3.6 \\
Swida macrophylla & 5.0 & 0.4 & 5.5 & 3.6 \\
Acer mono & 2.0 & 0.1 & 7.9 & 3.3 \\
Tilia paucicostata & 1.6 & 0.1 & 6.3 & 2.6 \\
Carpinus cordata & 1.3 & 0.0 & 5.5 & 2.3 \\
Juglans cathayensis & 1.3 & 0.1 & 4.7 & 2.0 \\
Bothrocaryum controversum & 2.2 & 0.1 & 3.1 & 1.8 \\
Rhus potaninii & 0.7 & 0.0 & 4.7 & 1.8 \\
Dendrobenthamia japonica var. chinensis & 0.7 & 0.0 & 3.9 & 1.6 \\
Pterocarya stenoptera & 2.2 & 0.1 & 2.4 & 1.5 \\
Acer davidii & 1.1 & 0.0 & 3.1 & 1.4 \\
Betula albo-sinensis & 0.9 & 0.0 & 3.1 & 1.3 \\
Betula albo-sinensis var. septentrionalis & 0.2 & 0.0 & 0.8 & 0.3 \\
Juglans mandshurica & 0.2 & 0.0 & 0.8 & 0.3 \\
Rhus punjabensis Stewart var. sinica & 0.1 & 0.0 & 0.8 & 0.3 \\
Prunus padus & 0.1 & 0.0 & 0.8 & 0.3 \\
Sorbus folgneri & 0.1 & 0.0 & 0.8 & 0.3 \\
Sum & 100.0 & 100.0 & 100.0 & 100.0 \\
\hline
\end{tabular}

2 Note: RH, RD, RF and IV in the table represent relative frequency, relative basal area and important value of tree species 3 respectively.

4

5

6

7

8 
Table 2 (on next page)

DBH distribution of dominant tree species

Big timber rate of domiant tree species was calculated in text. 
Table 2 DBH distribution of dominant tree species

\begin{tabular}{|c|c|c|c|}
\hline \multirow{2}{*}{$\begin{array}{l}\text { Mid-diameter } \\
\qquad(\mathrm{cm})\end{array}$} & \multicolumn{3}{|c|}{ Ratio of tree species } \\
\hline & Pinus tabuliformis & Pinus armandi & Quercus aliena var. acuteserrata \\
\hline 4 & 0.65 & 1.47 & 38.89 \\
\hline 8 & 2.58 & 3.68 & 38.89 \\
\hline 12 & 3.23 & 18.38 & 10.19 \\
\hline 16 & 5.81 & 20.59 & 3.70 \\
\hline 20 & 16.77 & 18.38 & 3.70 \\
\hline 24 & 12.26 & 14.71 & 1.85 \\
\hline 28 & 23.87 & 8.82 & 2.78 \\
\hline 32 & 14.19 & 5.88 & \\
\hline 36 & 10.32 & 5.15 & \\
\hline 40 & 7.10 & 2.94 & \\
\hline 44 & 2.58 & & \\
\hline 48 & 0.65 & & \\
\hline sum & 100 & 100 & 100 \\
\hline
\end{tabular}

2 


\section{Table 3 (on next page)}

Leaf stoichiometric traits of plants

TN, TP, N: P and IV in the table represents leaf concentration of total nitrogen, phosphorus and N: P ratio both in dominant tree species and plants, and importance value of tree species respectively. Extremely significant differences $(p=0.000)$ of leaf TN were between tree species. Extremely significant differences $(p=0.000)$ of leaf TN were between tree species.Extremely significant differences $(p=0.000)$ of leaf TP were between Quercus aliena var. acuteserrata-Pinus tabuliformis and Quercus aliena var. acuteserrata-Pinus armandi. Not significant difference $(p=0.88)$ of leaf TP was between Pinus tabuliformis- Pinus armandi.

Significant differences of leaf N:P were between Pinus tabuliformis- Pinus armandi $(p=0.048)$ and Pinus tabuliformis- Quercus aliena var. acuteserrata $(p=0.04)$. Not significant difference $(p=0.91)$ of leaf N:P was between Quercus aliena var. acuteserrata-Pinus armandi. 
Table 3 Leaf stoichiometric traits of plants

\begin{tabular}{lccccccc}
\hline \multicolumn{1}{c}{ Tree species } & $\begin{array}{c}\mathrm{TN} \\
\left(\mathrm{mgg}^{-1}\right)\end{array}$ & $\begin{array}{c}\mathrm{TP} \\
\left(\mathrm{mg}^{-1}\right)\end{array}$ & $\mathrm{N}: \mathrm{P}$ & $\begin{array}{c}\mathrm{IV} \\
(\%)\end{array}$ & $\begin{array}{c}\mathrm{TN} \\
\left(\mathrm{mg} \mathrm{g}^{-1}\right)\end{array}$ & $\begin{array}{c}\mathrm{TP} \\
\left(\mathrm{mg} \mathrm{g}^{-1}\right)\end{array}$ & $\begin{array}{c}\mathrm{N}: \mathrm{P} \\
\text { ratio }\end{array}$ \\
\hline Pinus tabuliformis & $11.84 \pm 1.40 \mathrm{~A}$ & $1.23 \pm 0.22 \mathrm{a}$ & $9.62: 1 \mathrm{a}$ & 35.2 & & & \\
& & & & & & & \\
Pinus armandi & $12.98 \pm 1.43 \mathrm{~B}$ & $1.20 \pm 0.14 \mathrm{a}$ & $10.82: 1 \mathrm{~b}$ & 20.1 & 9.08 & 0.88 & $10.30: 1$ \\
Quercus aliena var. acuteserrata & $21.72 \pm 3.19 \mathrm{C}$ & $2.00 \pm 0.31 \mathrm{~A}$ & $10.87: 1 \mathrm{~b}$ & 10.6 & & & \\
\hline
\end{tabular}

2 Note: TN, TP, N: P and IV in the table represents leaf concentration of total nitrogen, phosphorus and N: P ratio 3 both in dominant tree species and plants, and importance value of tree species respectively. Extremely significant 4 differences $(p=0.000)$ of leaf TN were between tree species. Extremely significant differences $(p=0.000)$ of leaf TP 5 were between Quercus aliena var. acuteserrata-Pinus tabuliformis and Quercus aliena var. acuteserrata-Pinus

6 armandi. Not significant difference $(p=0.88)$ of leaf TP was between Pinus tabuliformis- Pinus armandi. Significant

7 differences of leaf N:P were between Pinus tabuliformis- Pinus armandi $(p=0.048)$ and Pinus tabuliformis- Quercus

8 aliena var. acuteserrata $(p=0.04)$. Not significant difference $(p=0.91)$ of leaf N:P was between Quercus aliena var.

9 acuteserrata-Pinus armandi. 


\section{Table 4(on next page)}

Leaf stoichiometric traits of plants

TN, TP, N: P and IV in the table represents leaf concentration of total nitrogen, phosphorus and N: P ratio both in dominant tree species and plants, and importance value of tree species respectively. Extremely significant differences $(p=0.000)$ of leaf TN were between tree species. Extremely significant differences $(p=0.000)$ of leaf TP were between Quercus aliena var. acuteserrata-Pinus tabuliformis and Quercus aliena var. acuteserrata-Pinus armandii. Not significant difference $(p=0.88)$ of leaf TP was between Pinus tabuliformis-Pinus armandi. Significant differences of leaf N:P were between Pinus tabuliformis- Pinus armandi $(p=0.048)$ and Pinus tabuliformis- Quercus aliena var. acuteserrata $(p=0.04)$. Not significant difference $(p=0.91)$ of leaf N:P was between Quercus aliena var. acuteserrata-Pinus armandi. 
Table 4. Stoichiometric traits of mineral soil and litter

\begin{tabular}{|c|c|c|c|c|c|c|c|c|}
\hline \multirow{2}{*}{ Component } & \multirow{2}{*}{$\begin{array}{l}\text { Depth } \\
(\mathrm{cm})\end{array}$} & \multirow{2}{*}{$\begin{array}{c}\mathrm{TN} \\
\left(\mathrm{mg} \mathrm{g}^{-1}\right)\end{array}$} & \multirow{2}{*}{$\begin{array}{c}\mathrm{TP} \\
\left(\mathrm{mg} \mathrm{g}^{-1}\right)\end{array}$} & \multirow{2}{*}{$\mathrm{N}: \mathrm{P}$ ratio } & \multirow{2}{*}{$\begin{array}{l}\text { Bulk density } \\
\left(\mathrm{g} \mathrm{cm}^{-3}\right)\end{array}$} & \multirow{2}{*}{$\begin{array}{c}\text { Biomass } \\
\left(\mathrm{t} \mathrm{ha}^{-1}\right)\end{array}$} & \multicolumn{2}{|c|}{$\begin{array}{c}\text { Nutrients storage } \\
\left(\mathrm{t} \mathrm{ha}^{-1}\right)\end{array}$} \\
\hline & & & & & & & $\mathrm{TN}$ & $\mathrm{TP}$ \\
\hline \multirow{3}{*}{ Mineral soil } & $0-10$ & $2.40 \pm 0.10$ & $0.36 \pm 0.03$ & $(6.81: 1) \pm 0.51$ & $1.04 \pm 0.02$ & & \multirow{3}{*}{$4.58 \pm 0.15$} & \multirow{3}{*}{$0.95 \pm 0.09$} \\
\hline & $11-20$ & $1.20 \pm 0.04$ & $0.27 \pm 0.03$ & $(4.45: 1) \pm 0.39$ & $1.15 \pm 0.05$ & & & \\
\hline & $21-30$ & $0.60 \pm 0.05$ & $0.23 \pm 0.03$ & $(2.60: 1) \pm 0.41$ & $1.22 \pm 0.06$ & & & \\
\hline Mean & & 1.40 & 0.29 & 4.62 & & & & \\
\hline Litter & & $16.89 \pm 3.59$ & $1.51 \pm 0.24$ & $(11.51: 1) \pm 3.20$ & & $18.66 \pm 1.78$ & $0.31 \pm 0.07$ & $0.02 \pm 0.01$ \\
\hline
\end{tabular}

2 Note: TN, TP and N: P in the table represents leaf concentration of total nitrogen, phosphorus and N: P ratio both in soil and litter 3 respectively. 
Figure 1

Interaction of foliar N, P concentrations and N: P ratio of plants.

(a) Leaf concentrations of $\mathrm{N}$ and $\mathrm{P}$ in plants. (b) Leaf concentration of $\mathrm{N}$ and $\mathrm{N}: \mathrm{P}$ in plants. (c) Leaf concentration of $\mathrm{P}$ and $\mathrm{N}: \mathrm{P}$ in plants.

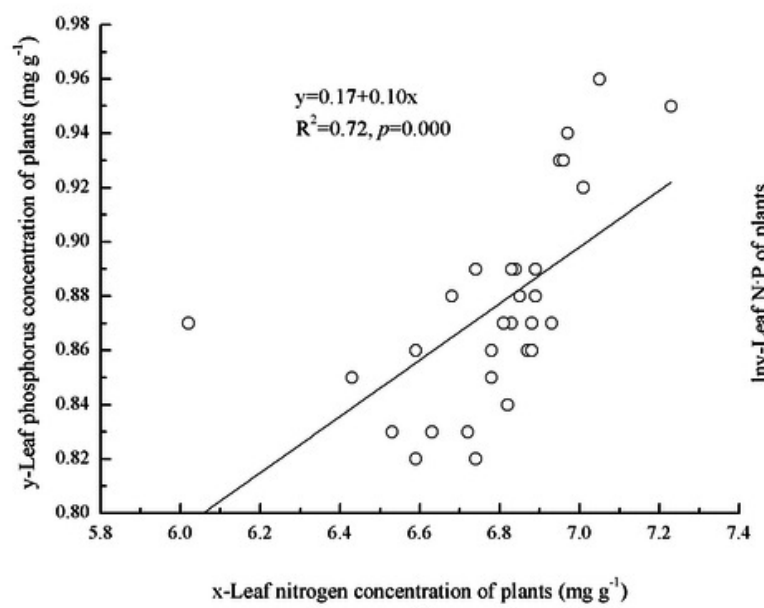

(a)

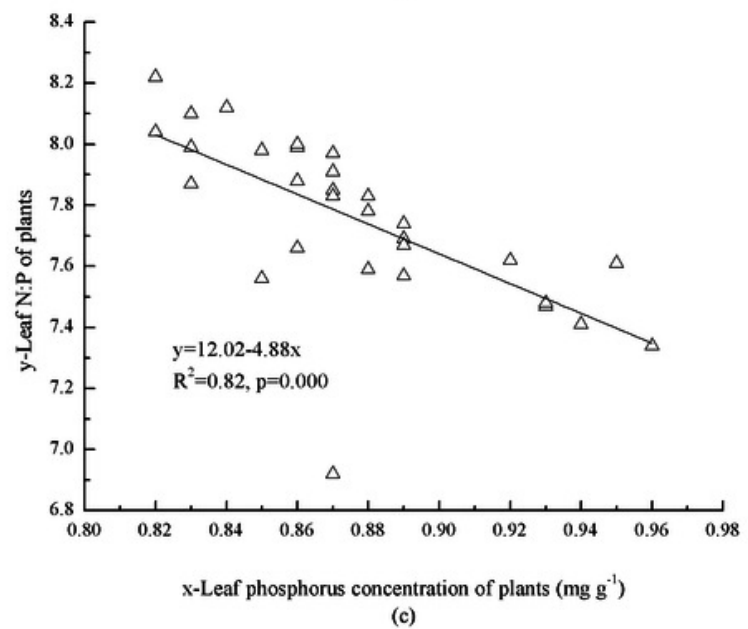

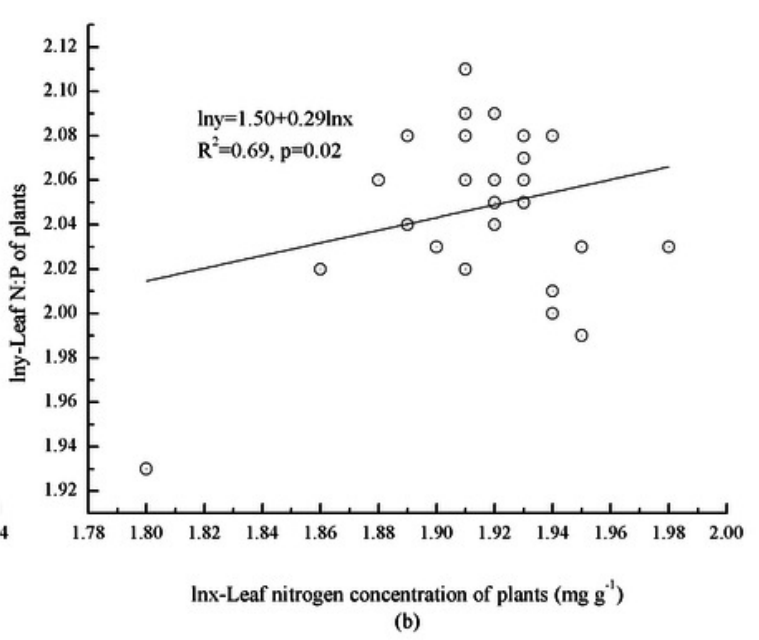

(b) 
Figure 2

Interaction of litter nutrients and mineral soil nutrients.

(4) Nitrogen concentrations of litter and miner soil within $0-10 \mathrm{~cm}$. $]$ Nitrogen concentrations of litter and miner soil within 11-20 cm. $\quad$ Nitrogen concentrations of litter and miner soil within 21-30 cm. . Phosphorus concentrations of litter and miner soil within 0-10 cm. $\quad$ Phosphorus concentrations of litter and miner soil within $11-20 \mathrm{~cm}$. $\quad$ Phosphorus concentrations of litter and miner soil within $21-30 \mathrm{~cm}$.

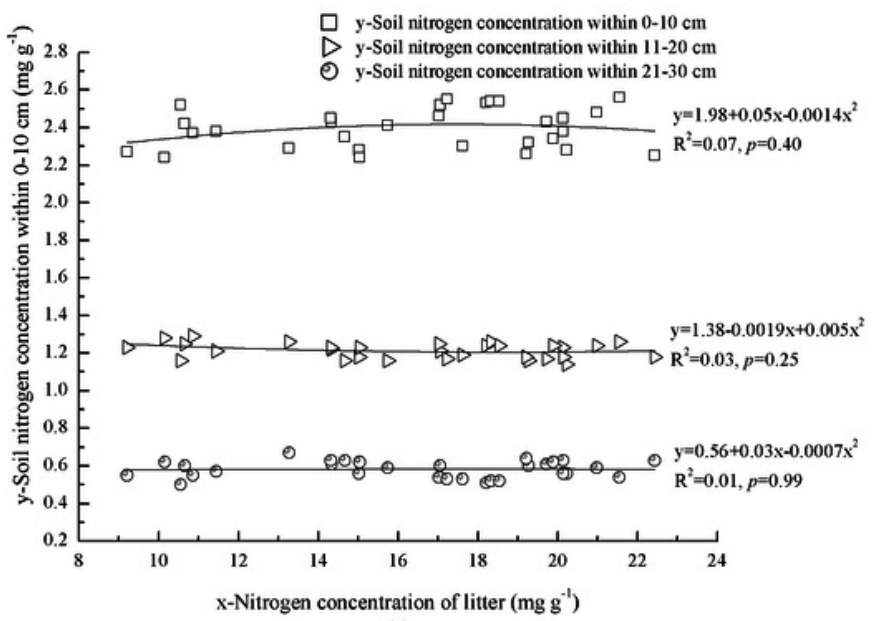

(a)

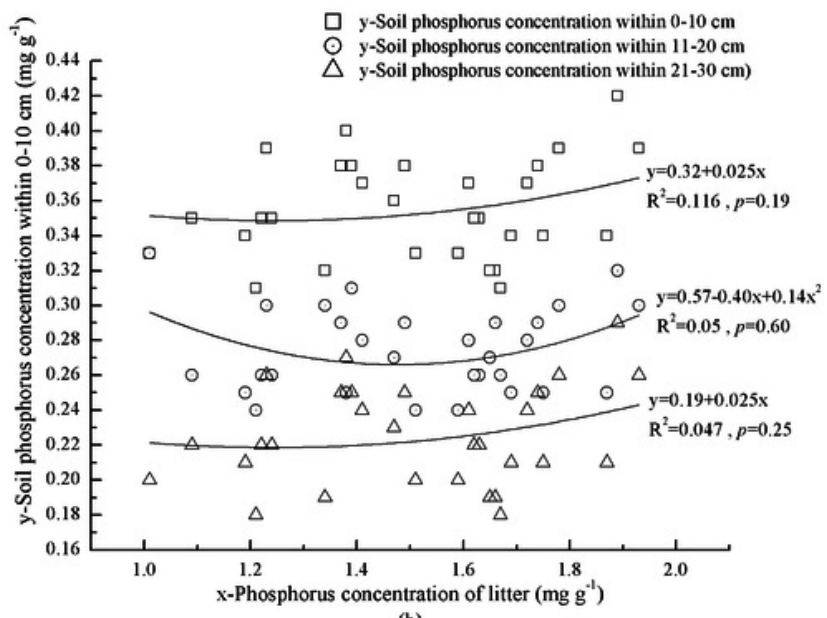

(b) 


\section{Figure 3}

Mineral soil nutrients and foliar nutrients of plants interaction.

( N Nitrogen concentrations of miner soil within $0-10 \mathrm{~cm}$ and leaf in plants. $\quad$ Nitrogen concentrations of miner soil within $11-20 \mathrm{~cm}$ and leaf in plants. $\mathrm{N}$ Nitrogen concentrations of miner soil within $21-30 \mathrm{~cm}$ and leaf in plants. $\mathrm{P}$ Phosphorus concentrations of miner soil within 0-10 cm and leaf in plants. $\quad$ Phosphorus concentrations of miner soil within $11-20 \mathrm{~cm}$ and leaf in plants. Phosphorus concentrations of miner soil within $21-30 \mathrm{~cm}$ and leaf in plants.
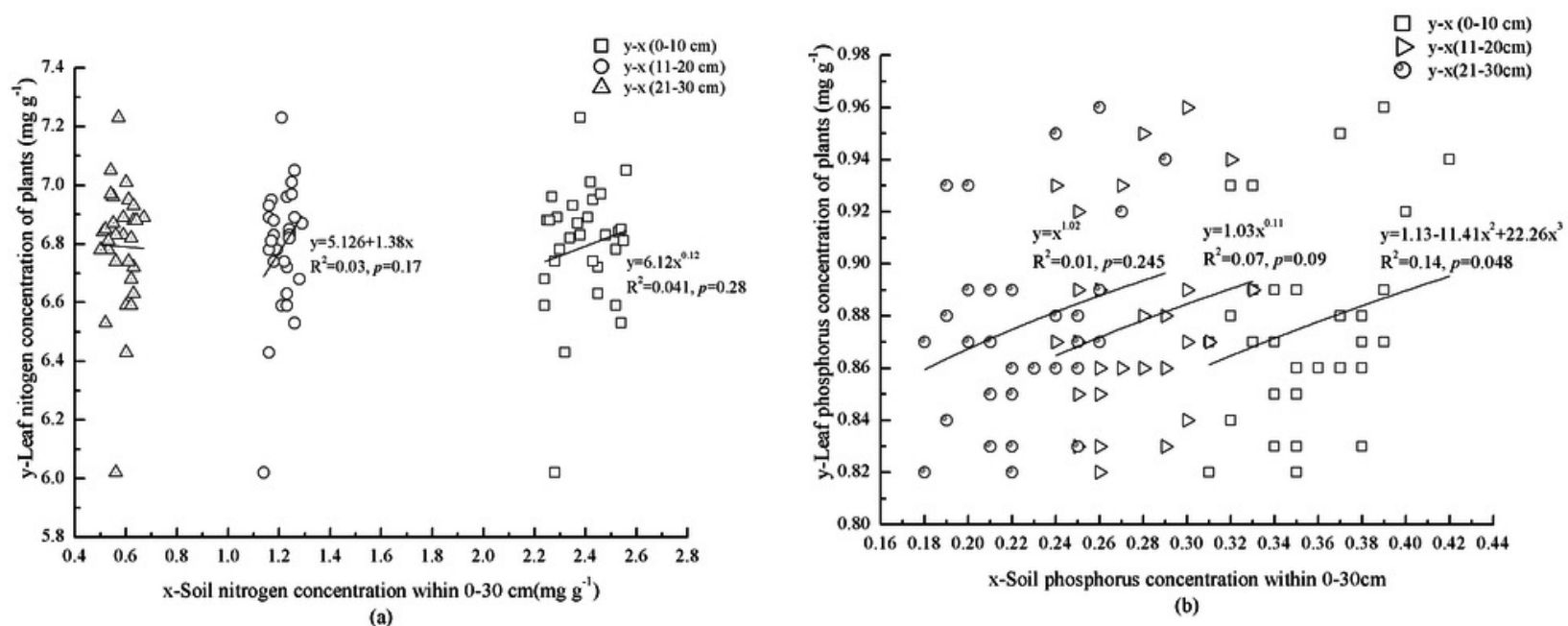


\section{Figure 4}

Relationships between storage of soil nutrients and foliar N: P ratio of plants.

(a) Relationship between nitrogen storage of mineral soil and N: P ratio of plants. (b) Relationship between phosphorus storage of mineral soil and N: P ratio of plants.
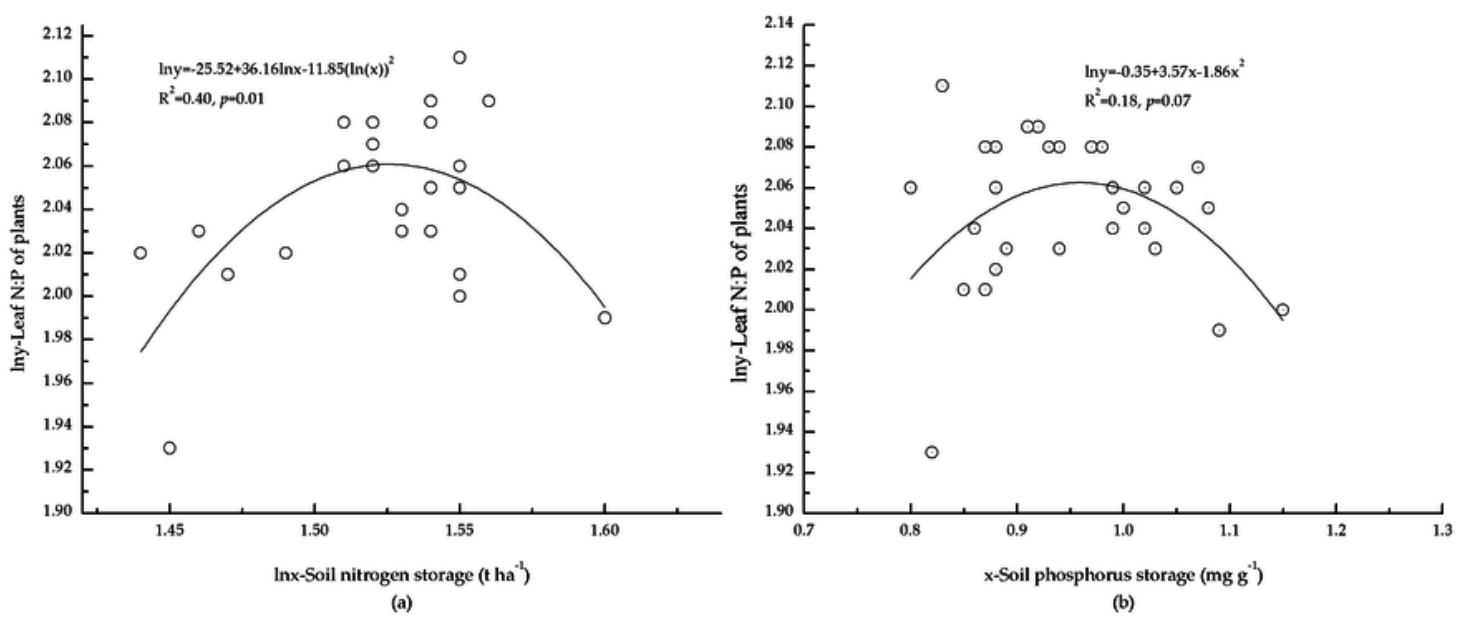